\title{
Evolution and management of humid landscapes in Northern Dauphiné (Rhône valley, France): contribution of charcoal and wood studies*
}

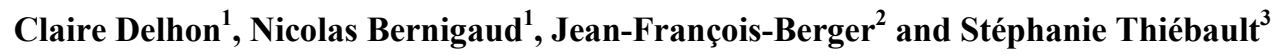

1 Université Nice Sophia Antipolis, Campus Saint-Jean-d'Angély, SJA3 - CEPAM- UMR 6130 CNRS, 24, avenue des Diables Bleus, F-06357 Nice Cedex 4, France; claire.delhon@cepam.cnrs.fr.

2 CNRS UMR 5600 Environnement, Ville et Société \& IRG, Campus Portes des Alpes, 5 avenue Pierre Mendès-France, Bâtiment L, F-69676 Bron cedex; Jean-Francois.Berger@univ-lyon2.fr

3 Muséum national d'Histoire Naturelle, UMR 7209 du CNRS : Archéozoologie, Archéobotanique: sociétés, pratiques et environnements, case postale 56, 55 rue Buffon, F-75005 Paris (France); thiebault@mnhn.fr

\begin{abstract}
Summary: The humid plains of the lower Dauphine area, located at the foothills of the northern French pre-Alps, between Grenoble and Lyon, are made of a complex of glacial and fluvial morphologies that have been occupied during a major part of the Holocene by marshes. In the framework of two programs funded by the Ministère de la Culture et de la Communication and the Agence Nationale de la Recherche, "PCR Peuplement et Milieu en Bas-Dauphiné (Isle Crémieu), de l'apparition de l'agriculture à l'époque moderne"(J.-F. Berger dir.) and "PaléohYdroloGy and huMAn-cLimate-envIronment interactiONs in the Alps" ("Pygmalion", F. Arnaud dir.) and thanks to numerous archaeological operations previous to various building works, we had the opportunity to study the management of these peculiar landscapes by human societies since the Neolithic. A dozen of sites, mainly "natural" sequences and palaeohydrological structures (palaeochannel and drainage/irrigation ditches), but also "real" archaeological occupations, have provided wood charcoal and/or imbibed wood remains. It appears that vegetation changes recorded by charcoal and wood assemblages are mainly related to local changes (soils, local humidity) and triggered by human management of the swamps.
\end{abstract}

Key words: charcoal analysis, humid landscape management, hydrological systems, vegetation, Bas Dauphiné

\section{INTRODUCTION}

The humid plains of the lower Dauphiné areas are located at the foothills of the northern French pre-Alps, between Grenoble and Lyon. Colluvio-alluvial and/or lacustrine sedimentation progressively filled the glacial basin during the first part of the Holocene, before the development of peats during the Neolithic (Berger et $a l ., 2008)$. In spite of its being occupied by marshes during the major part of the Holocene, the area has been intensively used by human societies since prehistoric times (Bernigaud et al., in press).

Thanks to numerous archaeological operations previous to various building works, we had the opportunity to study the management of these peculiar landscapes since the Neolithic. A dozen of sites (Fig. 1), mainly "natural" sequences and palaeohydrological structures (palaeochannel and drainage/irrigation ditches), but also "real" archaeological occupations, have provided wood charcoal and/or imbibed wood remains.

Charcoal from archaeological sites gives information on the wood gathered for fuel, which is usually collected in the surroundings (Chabal, 1997). Charcoal from hydraulic structures and fluvial archives witnesses either natural vegetation fire or anthropic activities, such as bank cleaning or agricultural fires (Delhon, 2005). Finally, imbibed wood remains have been found in peaty deposits, where they deposited and preserved in situ, or in the infilling of hydraulic structures and rivers palaeochannels.

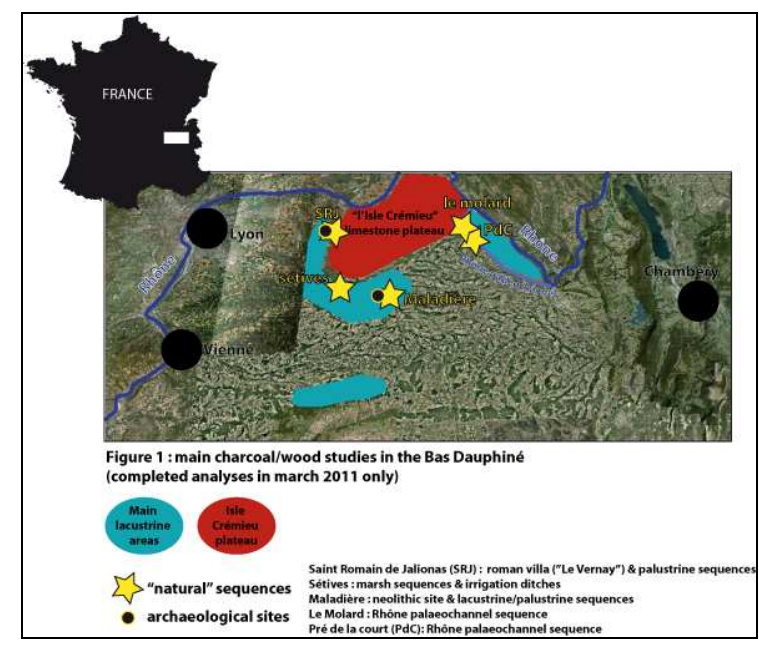

\section{RESULTS AND DISCUSSION}

It appears (Fig. 2) that vegetation changes recorded by charcoal and wood assemblages are mainly related to local changes (soils, local humidity) and triggered by human management of the swamps. They also document human practices (cleaning of the river banks, agricultural practices), and climate impact seems to have only a secondary importance in local vegetation changes. Nevertheless, occurrences of mountain species (fir: Abies alba) or Mediterranean species 
(sclerophyllous oak: sclerophyllous Quercus) have been recorded and could have a climatic meaning.

\section{ACKNOWLEDGEMENTS}

This study is part of the programe "PCR Peuplement et Milieu en Bas-Dauphiné (Isle Crémieu), de l'apparition de l'agriculture à l'époque moderne », funded by the french Ministère de la Culture et de la Communication and of the program "Pygmalion» funded by the ANR. Most of the 14C dates were done thanks to the «Artemis » program.

\section{REFERENCES}

BERGER, J.-F., SALVADOR, P.-G., FRANC, O., VEROT-BOURRELY, A., BRAVARD J.-P., 2008. La chronologie fluviale postglaciaire du haut basin rhodanien. Collection EDYTEM, cahier de Paléoenvironnement 6, 117-144.

BERNIGAUD, N., BERGER, J.-F., BLEU, S., BOUBY, L., DELHON, C., FRANC, O., GAUCHER, G., LATOUR-ARGANT, C., in press.
La bonification antique des grands marais de Bourgoin-la-Verpillière (Isère) : colonisation, grande hydraulique agricole et mise en culture pendant le Haut-Empire. Les cahiers du centre de recherches en histoire et histoire de l'Art. Italie, pays alpins.

CHABAL, L., 1997. Forêts et sociétés en Languedoc (Néolithique final, Antiquité tardive). L'anthracologie, méthode et paléoécologie. DAF 63, Editions de la Maison des Sciences de l'Homme, Paris.

DELHON C., 2005. Anthropisation et paléoclimats $d u$ Tardiglaciaire à l'Holocène en moyenne vallée $d u$ Rhône: études pluridisciplinaires des spectres phytolithiques et pédo-anthracologiques de séquences naturelles et de sites archéologiques. Ph.D. Thesis, Université Paris I.

* Caution: the present abstract deals with a work which is still in progress. The results are likely to evolve towards slightly different conclusions. Please cite the definitive publication, when available. March 2011.

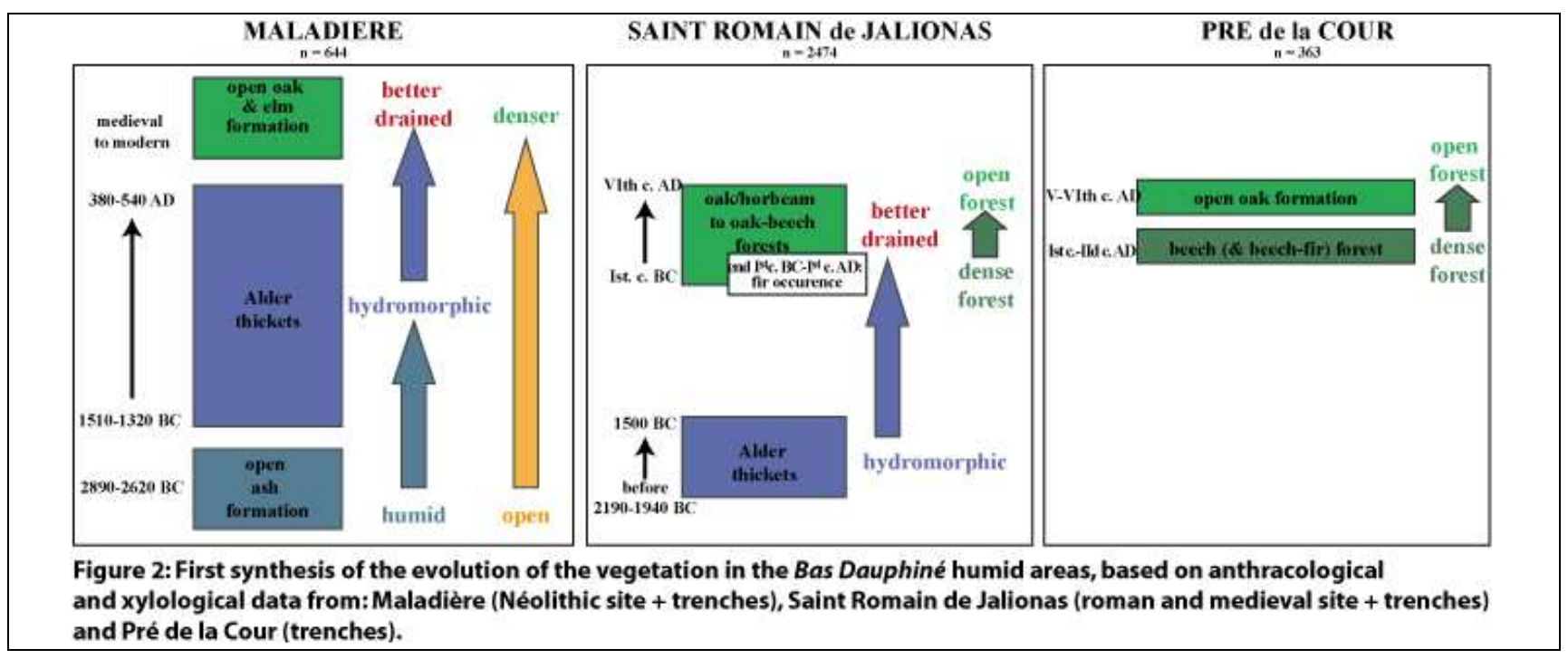

